\title{
PUBLIC GOVERNANCE: Factors of disclosure from the municipalities of southern Brazil
}

\author{
Vagner Naysinger Machado \\ Universidade do Vale do Rio dos Sinos - UNISINOS \\ Mail: Rua Almirante Abreu, 139/802 - Porto Alegre - RS - Brazil - CEP - 90420.010
}

Phone: (55) 5192592242 Email: vagner29colorado@gmail.com

Clea Beatriz Macagnan (Corresponding author)

Universidade do Vale do Rio dos Sinos - UNISINOS/ CNPq and CAPES/ Massachusetts Institute of Tecnology - MIT - Sloan School of Management.

59, Parkman St, Brookline - MA - USA

Phone: (1) 6173142323 Email: cleabeatrizm@gmail.com and clea@mit.edu

Doi:10.5296/ jpag.v5i4.8409 URL: http://dx.doi.org/10.5296/ jpag.v5i4. 8409

\begin{abstract}
Governance could be 'good' "when a State efficiently provides public goods of necessary quality to its citizens" (ONU, 2007). Public governance is guided by principles like transparency; that means disclosure information of public resources management. Considering this perspective, this study investigates the explanatory factors of the level of disclosure of the most populous municipalities in southern Brazil on their web pages published on the Internet. For such, we constructed a set of 86 indicators representing information, which were used to measure the level of disclosure of 100 among 101 cities with over 50,000 inhabitants in southern Brazil. The econometric analysis of the evidence indicates that the partisan affiliation of mayors, the level of revenues of municipalities and socioeconomic factors explain the level of disclosure of information about municipal management. Thus, the municipalities with high socioeconomic and collection indices have greater willingness to show public information, while municipalities where mayors are affiliated with the political party PSDB statistically have a tendency to show less information indicators examined in this study, compared to the other parties that make up this study sample.
\end{abstract}

Keywords: Transparency; Disclosure; Public Management; Local Government; Public Information. 


\section{Introduction}

The political-administrative organization of Brazil as defined in the Constitution of 1988 consists of the Union, Member States, the Federal District and the Municipalities. With decentralization, the municipalities have assumed many social duties (Gerigk, 2008). However, there is not always an alignment between actions of those responsible for municipal administration and the interest of the community (Cruz et al. 2012). In this context, the disclosure of information about municipal management could minimize the effects of information asymmetry on social contractual relationship, legitimizing their managers In this context, the disclosure of information about municipal management could minimize the effects of information asymmetry on social contractual relationship, legitimizing their managers and design the public governance.

Signaling public governance, the Brazilian legislation establishes a set of devices that regulate the mandatory disclosure of information by public agencies. The Complementary Law No. 101 of May 4, 2000, known as the Fiscal Responsibility Law and Law No. 12,527 of November 18, 2011, known as Law on Access to Information (LAI). Both laws establish rules for and use of the Internet as a tool for public disclosure of information. This gives opportunity to the cost reduction of citizenship and communication with society (Santana Junior, 2008 and Mello and Slomski, 2010).

In theory, Brazilian municipalities should comply with the legal provisions issued by the federal government in the matters related to transparency and disclosure of public information required. However, studies such as Souza et al. (2008) and Cruz et al. (2012) indicate levels of disclosure of information among the different municipalities surveyed. Socioeconomic, financial, cultural and historical aspects, among others, could influence the level of disclosure of municipal administrations and would explain the provision or not of public managers in disclosing information about their municipal administrations.

In this context, this study aims at identifying explanatory factors of the level of disclosure of municipalities in southern Brazil in their webpages published on the Internet. Thus, it is intended to reflect on what would take public managers to show the information as its management. The guide would enable public administrations to develop policies evidencing efficient information, contributing to the process of legitimacy in the communicative relationship between public managers and society, strengthening the social contract.

\section{Brazilian public management and disclosure of information}

Brazil is organized in the form of a federal republic, composed of federal entities, Union, states, municipalities and the Federal District (CF, 88). The main function of these public entities is the provision of public services, with the purpose of providing social welfare (Manning and Krann 2006). It happens that one should consider that public managers can act on behalf of their own interests (Bryanti and Davis 2012). With no information about public management, society would be the margin of decision making which would make difficult the use of legal instruments predict for the exercise of social control (Arruda and Telles 2010). 
While the information asymmetry between public management and society facilitates corrupt actions, illegal practices or misuse of public resources by public management, the disclosure of information of public management would enable the society to evaluate their representatives and support them or replace them by the electoral process. The disclosure of information relating to public administration would be a mechanism that would allow the public manager to establish effective communication as it minimizes the level of information asymmetry between public management and society. Still, it would be through the disclosure of information that society would legitimize or not the public management. In this context, the aspects of transparency through the disclosure of information would be evident in the efforts of organizations and would be a moral and political imperative associated with responsible, democratic and legitimate governance (Gupta 2008).

In recent decades, a political reform of the disclosure and access to information for a more transparent public management can be noticed in overall levels (Relly and Sabharwal 2009; Mendel 2009). In this sense, the disclosure of information assumes a relevant role for achieving better levels of transparency (Saw 2003). In Brazil, the main legal provisions related to disclosure of mandatory information on Brazilian public sector are:

(a) Law No. 4,320 of March 17, 1964 that stipulates general rules for the preparation of financial law and controlling of budgets and balances of public entities.

(b) Law No. 8666 of June 21, 1993 that establishes rules for bidding and procurement of public administration and establishes, among other principles, that of advertising.

c) Law No. 9,755 of December 16, 1998 that provides for the creation of a webpage in the Court of Audit (TCU) for dissemination of data and information regarding the management of public entities;

(d) Supplementary Law No. 101 of May 4, 2000 establishes standards of public finance for accountability in fiscal management. Known as the Fiscal Responsibility Law (FRL), its Article 48 of the LRF lists the instruments of transparency in fiscal management and establishes that widely disclosure will be given to these instruments, including on electronic means of public access.

(e) Law No. 10,028 of October 19, 2000 that amends the Decree-Law No. 2,848 of December 7, 1940. It amended the Civil Code and provides as administrative violation against the laws of public finances "not disclosing or submitting to the Legislature and the Court of Auditors Power the report of fiscal management at the terms and conditions established by law".

(f) Law No. 10. 257, June 10, 2001 regulates art. 182 and 183 of CF/88 and establishes general guidelines for urban policy. Focusing on municipalities, among other things, makes mandatory the disclosure of Municipal Development Plan.

(g) Complementary Law No. 131 of May 27, 2009 changes the LRF. The so-called Law of Transparency changed the LFR, because it established that transparency should be ensured by providing information on the budgetary and financial execution in real time on electronic means of access to the public. 
(h) Law No. 12,527 of November 18, 2011 that regulates the right of access to public information provided in the $\mathrm{CF} / 88$. Known as the Law on Access to Information (LAI) establishes a regulatory framework regarding public transparency in Brazil. The LAI regulates the procedures to be observed by the Federal Government, States, Federal District and Municipalities, in order to ensure the fundamental right of access to public information.

The voluntary disclosure would correspond to the willing of public managers to disclose information, which is not required by legal provisions. In this sense, there are international bodies, which work in order to promote transparency and disclosure of the managements of organizations, The International Monetary Fund (IMF), the International Federation of Accounts (IFAC), the Organization for Economic Cooperation and Development (OECD), and the non-governmental organization Transparency International (TI). In this line, it includes the Infoparticip@ project, developed by the laboratory of journalism and communication at the Autonomous University of Barcelona (Spain), that for compensating the lack of legislation on transparency since 2012 develops a map (www.mapainfoparticipa.com), which publishes the results in the evaluation of information evidenced by municipalities in their webpages from 41 indicators, with the aim of promoting good practices of local communication. Some of these indicators are considered as voluntary information in the present study.

\section{Empirical literature review and formulation of hypotheses}

From the empirical literature review was identified that one of the possible explanatory factors of the level of disclosure of information about the management would be the geographical location of the city. The results of the study by Cruz et al. (2012) point out that the location of the municipalities would be one of the explanatory factors of the level of transparency in municipal management. It is believed that the capitals and metropolitan cities are closer to the political and administrative center of the States, leading the city managers to adopt the decision of showing any more information. The location of a municipality in Brazil can mean differences in technological development or even technical / cultural migration, what would leave the hypothesis that the location could explain the level of disclosure of information.

H1. There is a relationship between the level of full disclosure in municipal management and the municipality location. Another factor that could explain the level of disclosure of information of municipal public management would be the partisan orientation of managers. The great diversity of ideologies between the political parties in Brazil can point to different levels of disclosure. The results of the study by Cruz et al. (2012) indicate that political issues would not be related to the level of disclosure of the municipalities. On the other hand, the results of studies of Styles and Tennyson (2007); Gandia and Archidona (2008) and Grimmelikhujsen and Welch (2012) point out that partisan political issues influence the level of transparency of governments. In this context, it is assumed the following hypothesis:

H2. There is a relationship between the level of full disclosure of public management of municipalities and the party affiliation of the mayor. 


\section{Macrothink}

The different sizes of cities could indicate a different behavior of public managers in terms of level of disclosure of information. Be the measured relative to size its territory or the number of its population. In this context, the study by Pérez, Bolivar and Hernández (2008) indicates that the population indices of municipalities would not explain the level of transparency of its managements. However, Cruz et al. (2012) show that the total population of cities would influence the level of transparency and disclosure in municipal management. Thus, it is assumed that the size of the municipalities would explain the level of disclosure of its managements.

H3. There is a relationship between the level of full disclosure in municipal management and the municipality size.

The level of economic development of the municipality could motivate public managers to establish better communication with society, which would mean greater level of disclosure. In this regard, studies of Styles and Tennyson (2007) and Cruz et al. (2012) indicate that economic factors such as GDP per Capita of municipalities would be explanatory factors of the level of transparency of public management of municipalities. Santana Junior (2008) indicates that economic factors such as the collection and indebtedness of municipalities would present a strong association with the level of transparency of the Brazilian states. Thus, it is assumed that economic factors would explain the level of disclosure in municipal management.

H4. There is a relationship between the level of full disclosure of municipal administrations and the level of economic development of the respective municipality.

Finally, the level of social development could influence the level of disclosure of public management of the municipality. In this context, the study by Cruz et al. (2012) points out that the level of transparency would be strongly related to social indicators of the municipalities. Santana Junior (2008) indicates the existence of this relationship in the Brazilian states. Therefore, it is assumed that social indicators would explain the level of disclosure of municipalities.

H5. There is a relationship between the level of full disclosure of municipal administrations and their social development.

From the empirical literature review and formulation of hypotheses, the research methodology presented in the next section was developed.

\section{Methodology}

To test the hypotheses formulated a set of variables was created representing them, comprising the model presented below.

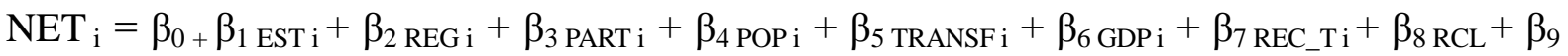
DCLi $+\beta_{10 \text { HDI i }}+\beta_{11 \text { ANALF } \mathrm{i}}+\beta_{12 \text { IFDM i }}+\beta_{13 \text { IRFS i }}+\beta_{14 \text { AREA }}+\varepsilon_{\mathrm{i}}$.

Table 1 - Variables of the statistical model. 


\begin{tabular}{|c|c|c|c|}
\hline Variables & & Variables & \\
\hline NET & Total level of disclosure & $\beta_{8 \mathrm{RCL}}$ & Net current revenue \\
\hline$\beta_{0}$ & Constant & $\beta_{9 \mathrm{DCL}}$ & Consolidated net debt \\
\hline$\beta_{1 \mathrm{EST}}$ & State & $\beta_{10 \mathrm{HDI}}$ & Human development index \\
\hline$\beta_{2 \text { REG }}$ & Region & $\beta_{11 \_ \text {ANALF }}$ & Illiteracy rate \\
\hline$\beta_{3 \text { PART }}$ & Political party & $\beta_{12 \_I F D M}$ & $\begin{array}{l}\text { FIRJAN index of municipal } \\
\text { development }\end{array}$ \\
\hline$\beta_{4} \mathrm{POP}$ & Total population & $\beta_{13 \_I R F S}$ & $\begin{array}{l}\text { Index for tax, social and manegment } \\
\text { responsibility }\end{array}$ \\
\hline$\beta_{5 \text { TRANSF }}$ & $\begin{array}{l}\text { Transfers of funds to } \\
\text { municipalities }\end{array}$ & $\beta_{14 \text { AREA }}$ & Territorial area \\
\hline$\beta_{6 \mathrm{GDP}}$ & GDP Per capita & $\mathrm{E}$ & Error $\mathrm{c}$ \\
\hline$\beta_{7 \text { REC_T }}$ & Total revenue collected & $\mathrm{i}$ & Municipalities \\
\hline
\end{tabular}

The Table 1 shows the variables of he statistical model. The next items we explain construction dependent variable.

\subsection{Dependent variable: total level of information disclosure.}

To determine the total level of disclosure of the city an empirical literature review was developed on the representative indicators of disclosure, as well as the Brazilian laws that determine information about municipal management that should be highlighted, what enabled the identification of representative indicators of information subsequently submitted to the evaluation of 3 experts on the subject. After validation, it was defined a set of 86 indicators of information, with 44 corresponding to mandatory information and 42 related to voluntary information.

If on one hand the selection of indicators of mandatory information was given based on Brazilian laws that regulate the disclosure of information in the public administration of the country, the set of voluntary indicators is the result of the adaptation to the Brazilian reality of the 41 indicators of information analyzed on the Infoparticip@ map developed by the laboratory of journalism and Communication at the Autonomous University of Barcelona (Spain), which can be considered a tool of political journalism, which aims at evaluating the public information released by the municipalities in their webpages regarding the citizen participation in the democratic control (Moreno, Molina, Corcoy, Aguilar, Borrás, 2013; 
Moreno Molina, Corcoy 2013).

In this sense, to measure the level of disclosure of public management, each indicator of information is assigned a score according to its disclosure. Two (2) points were scored to the indicators of information disclosed in full, one (1) point to indicators of information disclosed partially and those not recorded were assigned no point. It should be clarified that the evaluation of partial disclosure is given to those indicators of information composed of more than one parameter, which do not meet them all. Thus, the dependent variable: disclosure level may vary 0-172 points. The computation used in the preparation of disclosure index for each municipality follows the following formulation:

$$
I_{j}=\frac{\sum_{i=1}^{n} x_{i j}}{n_{j}}
$$

Where the expected number of indicators for each municipality corresponds to $\mathbf{n} \mathbf{j}$, the city is represented by the index $\mathbf{j}$, and the number of indicators is express by $\mathbf{i}$. When the indicator $\boldsymbol{X}_{\boldsymbol{i} j \text { is }}$ is evident, it takes the value 1,2 or 0 .

\subsection{Explanatory variables}

To test the hypotheses formulated, explanatory variables are assigned corresponding to the factors that would explain the level of full disclosure of public administrations, explained in the sequence:

\section{Hipothesis H1 - Location}

This hypothesis was contrasted with two variables, namely: the State of which the municipality belongs to and the region that the municipality belongs to.

(a) State (EST) Qualitative or dichotomous variable that consists of the distributing the municipalities with respect to their respective States. As this research studies the municipalities of southern Brazil, this variable can take three possibilities: Rio Grande do Sul (RS); Santa Catarina (SC) and Paraná (PR). Thus, it is a dummy for each State. The data relating to municipalities and their States were listed on the website of the Brazilian Institute of Geography and Statistics (IBGE), being based on the 2010 Census.

(b) Region (REG) Qualitative or dichotomous variable that corresponds to the grouping of municipalities according to their geographic locations in their respective State. For such, the classification of municipalities proposed by (IBGE) was used. Thus, a dummy was formulated with the following proxy: The value (zero) or 1 (one) to the municipalities located in the metropolitan areas of the State, including the capital, value of 0 (zero) for municipalities located within the State. Data were collected on the website IBGE based on the 2010 census.

\section{Hypothesis H2 - Partisan Affiliation of the municipal mayor.}

For the hypotheses of party affiliation of mayors was used the following variable: 
(c) Political Party (PART) Qualitative or dichotomous variable that consists of distributing the municipalities according to the mayor's political party. Firstly, political parties of elected mayors in the 2012 election were surveyed on the Supreme Electoral Tribunal (TSE) website. Accordingly, municipalities studied concentrate 13 different political parties. Therefore, this group of parties was segregated into five (5) dummies. As a parameter, 4 (four) parties were segregated, which according to the TSE concentrate greater numbers of municipalities throughout Brazil, namely: PMDB; PSDB; PT and PSD forming a dummy for each of them. The other dummy corresponds to the other political parties in the cities studied.

\section{Hypothesis H3 - Size}

In addition, for the hypothesis of city size, the following variables were considered:

(d) Total Population (POP) Quantitative variable that corresponds to the total population of the municipalities surveyed. The population is based on the 2010 census and the data were obtained on the IBGE website published on the Internet. Furthermore, for having no influence on the total amount of the sample population and a more appropriate statistical analysis, hundreds of the amount was disregarded from the total population of municipalities.

(e) Territorial area (AREA) Quantitative variable that corresponds to the total land area of the municipalities surveyed. Data were obtained on the IBGE website and are shown in $\mathrm{Km}^{2}$. However, we considered only the full value of the measurement area.

\section{Hypothesis H4 - Economic aspects.}

To check economic aspects, the following variables:

(f) Transfers of funds to municipalities (TRANSF) Quantitative variable that is the total amount of resource transfers made by the Union to the cities studied. Among these transfers, we highlight those made by transfer of funds from social funds. In this context, the amounts transferred to municipalities for the year 2012 were obtained. Data were collected on the website of the National Treasury Secretariat (STN) and refer to the sum of the values of "all funds". For statistical treatment was not considered hundreds and tens of total amounts of resource transfers to municipalities.

(g) GDP Per Capita (GDP) Quantitative variable that corresponds to the GDP per capita of the municipalities surveyed. The Gross Domestic Product (GDP) can be considered as a leading indicator of an economy and can be understood as the value added of all production from various sectors of society. The GDP per capita corresponds to the GDP value divided by total population of a country, state or municipality. In this sense, we obtained the GDP value per capita of the cities studied on the IBGE website and it corresponds to the values calculated based on the 2010 census. For a better statistical treatment are disregarded tens of values corresponding to GDP Per Capita of municipalities.

(h) Total Revenue collected (REC_T) Quantitative variable that refers to the total amount of revenues collected by municipalities for the year 2012. Data were obtained on the electronic pages of the prefectures available on the Internet. The information regarding the revenues collected from the municipalities that do not provide such information on their respective 
webpage were listed on the homepage of the National Treasury Secretariat (STN). Regarding the statistical analysis, we disregarded the hundreds and tens on the amounts of total revenues collected by municipalities.

(i) Net Current Revenue (RCL) Quantitative variable that corresponds to the amount of Net Current Revenue of municipalities for the year 2012. In this sense the Art. 2nd paragraph IV of LRF conceptualized the Net Current Revenue as the sum of all current revenues, subtracting the specific deductions predicted for each entity. The RCL is the calculation basis for all limits in LRF, highlighting the limits of personnel expenses, pension and debt (Santana Junior 2008). Data were obtained on the electronic pages of the cities available on the Internet or when not available, on the National Treasury Secretariat (STN) webpage. Statistical analysis did not consider the hundreds and tens on the amounts of net current revenues of the municipalities.

(j) Consolidated Net Debt (DCL) Quantitative variable that corresponds to the amount of the Consolidated Net Debt (DCL) of municipalities for the year 2012. The correct DCL calculation is predicted by the LRF and aims at ensuring transparency of obligations undertaken by public entities, and it is nothing more than the Consolidated Debt less any deductions (gross cash availability, liquid financial assets, free of processed payable remains). Data were collected on the electronic pages of the municipalities available on the Internet or when not available, on the website of the National Treasury Secretariat. For better statistical analysis was not considered the hundreds and tens of Consolidated Net Debt amounts of municipalities.

\section{Hypothesis H5 - Social Aspects}

Finally, to identify whether social aspects consisted of the following variables:

(k) Human Development Index (HDI) Quantitative variable that corresponds to the Human Development Index (HDI) of the municipalities. In 2012 UNDP Brazil in partnership with other institutions adapted the global HDI methodology and based on data from the IBGE 2010 census estimated the HDI of all Brazilian municipalities. Thus, the data for HDI of municipalities were obtained from the Atlas of Human Development in Brazil (2013 version) on the UNDP website (PNUD, 2013).

(I) Illiteracy rate (ANALF) Quantitative variable that corresponds to the rate of illiteracy in the cities studied. An illiterate person is one who cannot read and write a simple note in his mother tongue (IBGE, 2013). Based on data from the 2010 census, the PNUD (2013) found the rate of illiteracy of the municipalities. Thus, the data to construct this variable were obtained from the Atlas of Human Development in Brazil and correspond to the average percentage of the population aged 15 or older, who is illiterate. Thus, the lower the rate of illiteracy the better would be the level of education of the municipality.

(m) FIRJAN Index of municipal development (IFDM) Quantitative variable that corresponds to the FIRJAN index of municipal development (IFDM) of the municipalities surveyed. The FIDM can serve to identify possible shortcomings of the municipalities and guide public policies, as well as monitoring their impact on the development of municipalities. 


\section{Macrothink}

The FIDM is expressed as a number between 0 and 1 , and the closer to 1 the better the indicators of employment, health and education of the municipality. Data collected were related to the 2012 edition and based on official data for the year 2010, being available on the website of FIRJAN system.

(n) Index of tax, social and management responsibility (IFRS) Quantitative variable that corresponds to the index of fiscal, social and Management responsibility (IFRS) of the municipalities surveyed. The IFRS is developed by the National Confederation of Municipalities (CNM) and aims at encouraging improvements in local public administrations (Cruz et al. 2012). The FIRS is expressed as a number between 0 and 1, and the closer to 1 the higher the index. The index of fiscal, social and management responsibility of the cities studied refers to the data of the year 2011 and was obtained on the website of the National Confederation of Municipalities (CNM).

The population of this research consists of all 101 municipalities with over 50,000 inhabitants in southern Brazil. For analyzing the information available on the Internet were only considered the official webpages of municipalities, i.e. those with "gov" extension. The municipality of União da Vitoria/ PR was excluded for not having a webpage with this extension. Therefore, the sample consisted of 100 municipalities in the southern region of Brazil.

The collection of evidence to construct the variable to be explained: Level of disclosure (NS) was carried out in July 2013. It should be noted that the evidence collected is for the year 2012. Also, it was considered as a Multi-Year Plan (PPA) for the period preceding the 2006 to 2009, and PPA the current plan for the period 2010-2013. Budgetary Guidelines Law (LDO) and Annual Budget Law (LOA) above refer to the documents the year 2011, while the current LDO and LOA are corresponding to 2012. The data collection for the construction of the explanatory variables was performed in August 2013.

\section{Results and discussion}

This part is composed of two items: descriptive and correlational analysis and, the regression analysis of the variables.

\subsection{Descriptive and correlational analysis of the variables}

The descriptive analysis of the indicators representative of the 86 types of information, as evidenced in the electronic pages of the municipalities in the sample is presented in table 2. 
Table 2 - Descriptive analysis of the level of municipal information disclosure.

\begin{tabular}{lcccc}
\hline Information & Mean & Minimum & Maximum & $\begin{array}{l}\text { Standard } \\
\text { Deviation }\end{array}$ \\
\hline Level of mandatory disclosure & 50,33 & 21,00 & 78,00 & 11,64 \\
Level of voluntary disclosure & 35,24 & 17,00 & 57,00 & 8,61 \\
Level of full disclosure & 85,57 & 45,00 & 128,00 & 17,88 \\
\hline
\end{tabular}

The index that measures the level of disclosure of mandatory information (NEO) has mean of $57.19 \%$ of total of indicators. This indicates that managers are not complying with the legal requirements of disclosure. On the other hand, the index that measures the extent of voluntary disclosure of information (NEV) showed average of $41.95 \%$ of total indicators, which signs communication initiative of public managers. The index that measured the overall level of disclosure of information (NET) showed average of $49.75 \%$ of total indicators. This result is similar to the finding of Cruz et al. (2012), who reported a medium level of disclosure of $46.22 \%$ of the total, which can be considered as low level of disclosure. Moreover, the NET measurement allowed classifying municipalities.

Table 3 - Municipalities with higher levels of information disclosure.

\begin{tabular}{lllll}
\hline Position & Municipalities & State & Level Disclosure & $\%$ \\
\hline $1^{\text {o }}$ & Florianópolis & SC & 128 & 74,42 \\
$2^{\text {o }}$ & Curitiba & PR & 126 & 73,26 \\
$3^{\text {o }}$ & Londrina & PR & 126 & 73,26 \\
$4^{\text {o }}$ & Pinhais & PR & 123 & 71,51 \\
$5^{\circ}$ & Ijuí & RS & 120 & 69,77 \\
\hline
\end{tabular}

The Table 3 lists the five municipalities with higher levels of disclosure. In this sense, the municipality with the best performance for the disclosure of information is Florianópolis / SC, which scored 128 points, equivalent to $74.42 \%$ of total indicators. The cities of Curitiba, Londrina, Pinhais and Ijuí / RS complete the group of municipalities with higher levels of disclosure. Thus, the evidence shows that no municipality showed $100 \%$ of information investigated. This result is similar to the studies of Souza et al. (2008) and Cruz et al. (2012).

The only representative indicator of information displayed by all municipalities analyzed is 
related to the publication of news on the website of the prefectures. In addition to this indicator, the permission for recording of electronic reports and information regarding the expenditure are evidenced by most municipalities. On the other hand, no municipality released basic information: a biography or resume and email addresses of members of the opposition to the local government; information relating to discussions between government members, opposition and civil servants, as well as the publication of government agreements.

Table 4 - Descriptive analysis of quantitative variables.

\begin{tabular}{|c|c|c|c|c|}
\hline Quantitatives variables & Mean & Minimum & Maximum & $\begin{array}{l}\text { Standard } \\
\text { Deviation }\end{array}$ \\
\hline ANALF & 4,27 & 1,50 & 9,17 & 1,54 \\
\hline $\log A R E A$ & 6,33 & 3,29 & 8,96 & 1,21 \\
\hline $\log D C L$ & 9,99 & 6,90 & 13,66 & 1,54 \\
\hline HDI & 0,7553 & 0,6500 & 0,8470 & 0,0338 \\
\hline IFDM & 0,7947 & 0,6554 & 0,9607 & 0,0599 \\
\hline IRFS & 0,4757 & 0,3780 & 0,5950 & 0,0425 \\
\hline log GDP per capita & 9,92 & 8,67 & 11,55 & 0,48 \\
\hline $\log P O P$ & 4,74 & 3,91 & 7,46 & 0,71 \\
\hline $\log R C L$ & 12,22 & 11,18 & 15,44 & 0,82 \\
\hline $\log R E C_{-} T$ & 12,36 & 11,20 & 15,44 & 0,82 \\
\hline $\log T R A N S F$ & 10,96 & 10,09 & 13,18 & 0,56 \\
\hline
\end{tabular}

Concerning to the descriptive analysis of the explanatory variables, these can be segregated into quantitative and qualitative. In this context, table 4 shows the descriptive analysis of quantitative variables. It was chosen to estimate the variables in logarithms associated with economic aspects and cities size.

In addition, qualitative variables can be described as follows:

(a) State Variable (EST). Regarding the states, 42 municipalities belong to the state of Rio Grande do Sul (RS), 31 to Paraná (PR) and 27 to Santa Catarina (SC);

(b) Region Variable (REG). Among the cities studied, 71 are located within the states and 29 
in the metropolitan areas;

(c) Political party Variable (PART). Regarding the party affiliation of mayors, 25 mayors are affiliated to the PT (Workers' Party), 22 to PMDB (Party of the Brazilian Democratic Movement), 9 to PSDB (Social Party of Brazilian Democracy), 6 PSD (democratic social party) and 38 are affiliated with other political parties.

\begin{tabular}{|c|c|c|c|c|c|c|c|c|c|c|c|c|c|c|c|c|c|c|c|}
\hline$\stackrel{2}{ }$ & & & & & & & & & & & & & & & & & & & $\underset{-}{8}$ \\
\hline$\stackrel{\infty}{\rightarrow}$ & & & & & & & & & & & & & & & & & & $\underset{-}{\stackrel{8}{*}}$ & $\frac{1}{0}$ \\
\hline$=$ & & & & & & & & & & & & & & & & & $\underset{-}{-}$ & $\begin{array}{l}\tilde{0} \\
0 \\
\end{array}$ & $\frac{0}{0}$ \\
\hline$\stackrel{0}{\sim}$ & & & & & & & & & & & & & & & & $\underset{-}{\stackrel{8}{*}}$ & \begin{tabular}{|l|} 
\\
0 \\
\\
\end{tabular} & $\begin{array}{l}0 \\
0 \\
0\end{array}$ & : \\
\hline$\cong$ & & & & & & & & & & & & & & & $\underset{-}{8}$ & $\begin{array}{l}5 \\
\vdots \\
0\end{array}$ & \begin{tabular}{|l} 
\pm \\
$i$ \\
\end{tabular} & तે & $\begin{array}{l}\bar{N} \\
\tilde{0} \\
\end{array}$ \\
\hline \pm & & & & & & & & & & & & & & $\underset{-}{8}$ & : & $\begin{array}{l}n \\
0 \\
i \\
\end{array}$ & \begin{tabular}{|l|}
$\frac{\infty}{0}$ \\
1 \\
\end{tabular} & $\stackrel{8}{0}$ & $\begin{array}{l}\tilde{n} \\
\vdots \\
0\end{array}$ \\
\hline$\underline{n}$ & & & & & & & & & & & & & $\underset{-}{8}$ & $\begin{array}{l} \pm \\
0 \\
0 \\
\end{array}$ & $\begin{array}{l}m \\
0 \\
\end{array}$ & $\begin{array}{l}0 \\
0 \\
0\end{array}$ & \begin{tabular}{|c}
0 \\
0 \\
0 \\
0 \\
\end{tabular} & $\begin{array}{l}\stackrel{1}{0} \\
\stackrel{1}{1}\end{array}$ & $\begin{array}{l}n \\
0 \\
\end{array}$ \\
\hline$\simeq$ & & & & & & & & & & & & $\underset{-}{\stackrel{8}{*}}$ & $\begin{array}{l}8 \\
0 \\
i \\
\end{array}$ & $\begin{array}{l}\infty \\
0 \\
0\end{array}$ & $\frac{\infty}{0}$ & $=$ & \begin{tabular}{|l}
$\vec{y}$ \\
$\hat{i}$ \\
\end{tabular} & $\vec{m}$ & $\begin{array}{l}\tilde{\sigma} \\
\text { c. }\end{array}$ \\
\hline$=$ & & & & & & & & & & & $\underset{-}{8}$ & s. & 8 & $\begin{array}{l}\text { t. } \\
0\end{array}$ & $\frac{\infty}{0}$ & $\stackrel{8}{0}$ & \begin{tabular}{|l}
$n$ \\
ñ \\
$i$ \\
$i$
\end{tabular} & तે & $\begin{array}{l}0 \\
0 \\
0\end{array}$ \\
\hline$\stackrel{-}{1}$ & & & & & & & & & & $\underset{-}{8}$ & gे & sू & 8 & $\begin{array}{l}\Delta \\
0 \\
0\end{array}$ & $\frac{\infty}{0}$ & $\begin{array}{l}\tilde{O}_{0} \\
\stackrel{0}{0}\end{array}$ & $\begin{array}{l}\hat{n} \\
\hat{i} \\
i\end{array}$ & तે & $\begin{array}{l}0 \\
0 \\
\end{array}$ \\
\hline$a$ & & & & & & & & & $\underset{-}{8}$ & : & s. & $\hat{\mathrm{s}}$ & $\begin{array}{l}8 \\
0 \\
\end{array}$ & $\stackrel{\simeq}{0}$ & $\begin{array}{l}\text { त̃ } \\
0\end{array}$ & $\begin{array}{l}\infty \\
0 \\
0 \\
0\end{array}$ & \begin{tabular}{|l}
$\vec{y}$ \\
$\hat{i}$ \\
\end{tabular} & $\begin{array}{l}\stackrel{+}{2} \\
\stackrel{0}{0}\end{array}$ & $\begin{array}{l}\delta \\
0 \\
0\end{array}$ \\
\hline$\infty$ & & & & & & & & $\underset{-}{8}$ & $\begin{array}{l}\text { त̂ } \\
\text { s. }\end{array}$ & $\stackrel{f}{0}$ & 声 & ते & o. & $\frac{n}{0_{0}^{\prime}}$ & $\begin{array}{l}8 \\
0 \\
0\end{array}$ & $\begin{array}{l}\text { î } \\
\text { ô }\end{array}$ & $\begin{array}{l} \\
\\
\end{array}$ & $\begin{array}{l}8 \\
\text { i. } \\
\end{array}$ & a. \\
\hline$r$ & & & & & & & $\stackrel{8}{-}$ & $\overline{\tilde{\sigma}}$ & 尽 & 童 & 音 & 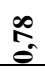 & $\delta_{0}$ & $\begin{array}{l}\infty \\
0 \\
0\end{array}$ & $\frac{0}{0}$ & $\frac{ \pm}{0}$ & \begin{tabular}{|l}
$\overline{\hat{y}}$ \\
$\underline{i}$
\end{tabular} & $\begin{array}{l}\text { ते } \\
\text { Oे }\end{array}$ & 8 \\
\hline 0 & & & & & & 8 & $\stackrel{8}{\circ}$ & $\begin{array}{l}t \\
0 \\
0\end{array}$ & $\stackrel{8}{0}$ & : & $\begin{array}{l}0 \\
\text { i. } \\
1\end{array}$ & o. & 莒 & $\begin{array}{l}n \\
\vdots \\
0\end{array}$ & $\begin{array}{l}\hat{b} \\
\dot{i} \\
\end{array}$ & $\begin{array}{l}\text { no } \\
0 \\
i\end{array}$ & $\begin{array}{l}0 \\
0 \\
0 \\
i\end{array}$ & $\begin{array}{l}\bar{n} \\
i \\
i\end{array}$ & $\begin{array}{l}8 \\
0\end{array}$ \\
\hline in & & & & & $\stackrel{8}{-}$ & $\begin{array}{l}8 \\
0 \\
\end{array}$ & $\begin{array}{l}\text { तิ } \\
\text { î }\end{array}$ & $\therefore$ & $\stackrel{5}{i}$ & $\begin{array}{l}\infty \\
\stackrel{+}{i}\end{array}$ & $\stackrel{0}{\circ}$ & $\frac{m}{i}$ & $\frac{7}{0}$ & $\begin{array}{l}\text { d. } \\
\text { ci } \\
\text { in }\end{array}$ & $\begin{array}{l}8 \\
0 \\
i\end{array}$ & $\begin{array}{l}\text { ô. } \\
\text { i. }\end{array}$ & $\begin{array}{l}0 \\
0 \\
0\end{array}$ & $\stackrel{0}{i}$ & $\begin{array}{l}\circ \\
i\end{array}$ \\
\hline$\theta$ & & & & $\stackrel{8}{-}$ & $\frac{ \pm}{0}$ & $\begin{array}{l}\text { त̃ } \\
\text { ô }\end{array}$ & $\begin{array}{l}\infty \\
\text { तै } \\
\text { d }\end{array}$ & $\begin{array}{l}0 \\
1 \\
0 \\
0\end{array}$ & fo & है & $\begin{array}{l}\infty \\
n \\
0 \\
0\end{array}$ & $\stackrel{f}{q}$ & \begin{tabular}{|l}
0 \\
0 \\
0 \\
\end{tabular} & $\frac{0}{0}$ & $\frac{n}{0}$ & $\begin{array}{l}0 \\
\stackrel{0}{1}\end{array}$ & $\begin{array}{l}m \\
0 \\
\end{array}$ & $\begin{array}{l}\text { s. } \\
0 \\
\end{array}$ & 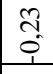 \\
\hline$m$ & & & $\underset{-}{8}$ & $\stackrel{5}{0}$ & $\begin{array}{l}\infty \\
\text { s. }\end{array}$ & $\begin{array}{l}\text { oे } \\
\text { i. }\end{array}$ & $\begin{array}{l}\text { İ } \\
\text { of }\end{array}$ & $\underset{0}{*}$ & If & $\begin{array}{l}\stackrel{0}{\circ} \\
:\end{array}$ & $\begin{array}{l}n \\
n \\
0\end{array}$ & i. & $\frac{\infty}{0}$ & $\stackrel{0}{\circ}$ & $\frac{\infty}{0}$ & $\begin{array}{l} \pm \\
\\
\end{array}$ & $\frac{\infty}{0}$ & $\frac{\infty}{0}$ & 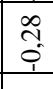 \\
\hline $\mathrm{N}$ & & $\underset{-}{8}$ & $\begin{array}{l}n \\
0 \\
i\end{array}$ & $\begin{array}{l}\hat{n} \\
\text { in }\end{array}$ & $\begin{array}{l}\text { Î } \\
\text { î }\end{array}$ & $\begin{array}{l}\text { J } \\
0\end{array}$ & $\begin{array}{l}\infty \\
\text { ît } \\
\text { î. }\end{array}$ & 1 & $\begin{array}{l}\text { qo } \\
\text { o }\end{array}$ & $\begin{array}{l}n \\
\hat{n} \\
\hat{i}\end{array}$ & $\begin{array}{l}\text { त̂ } \\
\text { in }\end{array}$ & $\stackrel{\text { fo }}{\stackrel{9}{i}}$ & $\begin{array}{l}\text { a } \\
0 \\
\end{array}$ & $\hat{n}$ & $\begin{array}{l}n \\
0 \\
0 \\
\end{array}$ & $\begin{array}{l}\text { to } \\
\text { i. }\end{array}$ & $\begin{array}{l}0 \\
0 \\
0 \\
0\end{array}$ & $\begin{array}{l}0 \\
\text { N1 } \\
\stackrel{1}{1}\end{array}$ & $\begin{array}{l}n \\
0 \\
0\end{array}$ \\
\hline- & $\underset{-}{\stackrel{8}{*}}$ & $\begin{array}{l}\text { లి } \\
\text { i. }\end{array}$ & है & 点 & $\stackrel{8}{0}$ & $\begin{array}{l}\overrightarrow{0} \\
0 \\
\end{array}$ & $\overrightarrow{\tilde{N}}$ & If & fr & 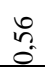 & $\begin{array}{l}n \\
n \\
0\end{array}$ & $\stackrel{?}{q}$ & $\begin{array}{l}\infty \\
0 \\
0\end{array}$ & $\stackrel{0}{0}$ & $\because$ & $\begin{array}{l}\text { J̀ } \\
\text { ô }\end{array}$ & $\begin{array}{l} \pm \\
i \\
i\end{array}$ & $\tilde{0}_{0}$ & $\frac{0}{i}$ \\
\hline & 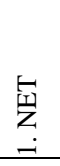 & 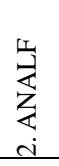 & $\underset{\text { 空 }}{\overrightarrow{7}}$ & 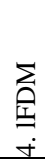 & 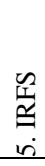 & $\begin{array}{l}\frac{}{4} \\
\frac{1}{4} \\
0 \\
0 \\
0\end{array}$ & $\begin{array}{l}\vec{U} \\
\underline{a} \\
\stackrel{0}{0} \\
\stackrel{n}{n}\end{array}$ & 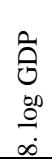 & 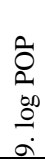 & $\begin{array}{l}\vec{U} \\
\cong \\
\stackrel{0}{\circ} \\
\stackrel{0}{0}\end{array}$ & 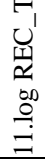 & $\begin{array}{l}\stackrel{60}{\stackrel{1}{I}} \\
\stackrel{1}{I}\end{array}$ & 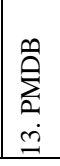 & $\begin{array}{l}\stackrel{\alpha}{\alpha} \\
\dot{ \pm}\end{array}$ & $\begin{array}{l}\hat{0} \\
\hat{n} \\
\omega \\
n\end{array}$ & 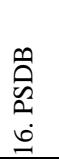 & \begin{tabular}{|l}
5 \\
$\Sigma$ \\
$I$
\end{tabular} & \begin{tabular}{l}
0 \\
\multirow{w}{*}{} \\
$\infty$ \\
$\underline{\infty}$
\end{tabular} & $\hat{\approx}$ \\
\hline
\end{tabular}

Table 5: Correlacion

Before the estimation of models of multiple linear regression was performed the test for multicollinearity, according to Table 5, which allows to observe the variables: Net Consolidated Debt (log DCL). Population (log POP); Net Current Revenue (log RCL); Total Revenue (log REC_T) and Transfer of resources (log TRANSF) show high levels of correlation. Along the same lines, the variable Human Development Index (HDI) and the variable FIRJAN index of Municipal Development (IFDM) also feature correlation 
coefficient above 0.60 . To exclude variables with high correlation, we chose to exclusion according to their significance in the statistical model. In this sense, it was used 5\% significance.

\subsection{Regression analysis}

Multiple linear regression models were estimated by the method of least squares. In each model was retained only the variables with high correlation.

Table 6 - Result of the final model estimate for the NET index.

Dependent Variable: NET

Method: Least Squares

Included Observations: 100

\begin{tabular}{l|llll}
\hline Variables & Coefficient & $\begin{array}{l}\text { Std. } \\
\text { Error }\end{array}$ & t-Statistic & Prob. \\
log RCL & $\mathbf{8 , 5 7 0 3 7 2}$ & $\mathbf{2 , 1 2 3 6 3 7}$ & $\mathbf{4 , 0 3 5 7 0 4}$ & $\mathbf{0 , 0 0 0 1}$ \\
IFDM & $\mathbf{8 3 , 9 8 5 2 2}$ & $\mathbf{2 9 , 1 0 6 4 7}$ & $\mathbf{2 , 8 8 5 4 4 9}$ & $\mathbf{0 , 0 0 4 9}$ \\
PSDB & $\mathbf{- 1 4 , 2 4 4 2 4}$ & $\mathbf{5 , 1 7 8 2 5 5}$ & $\mathbf{- 2 , 7 5 0 7 8 0}$ & $\mathbf{0 , 0 0 7 1}$ \\
PMDB & 1,950411 & 3,714916 & 0,525022 & 0,6008 \\
PT & $-1,622348$ & 3,633026 & $-0,446556$ & 0,6562 \\
PSD & $-0,423599$ & 6,114215 & $-0,069281$ & 0,9449 \\
CONSTANT & $-84,65653$ & 23,15084 & $-3,656736$ & 0,0004 \\
\hline R- squared & 0,442971 & & Adjusted R- squared & $\mathbf{0 , 4 0 7 0 3 4}$ \\
F- statistic & $\mathbf{1 2 , 3 2 6 2 0}$ & & Prob (F - statistic) & $\mathbf{0 , 0 0 0 0 0 0}$ \\
Durbin-Watson & $\mathbf{2 , 2 0 1 4 2 7}$ & & & \\
\hline
\end{tabular}

Table 6 shows the result of the final model estimate for the NET index. To validate the estimated model were performed the autocorrelation tests of Durbin-Watson, which reported a prob (stat. F) of 2.201427 and, the Breusch-Godfrey, which found a statistics (F) of 0.5761 and a prob (F) of 0.5641 . These results allow us to accept the null hypothesis test, which indicates the absence of autocorrelation. In addition, there were the heteroskedasticity tests of 


\section{Macrothink}

White, which found a statistics (F) of 0.6574 and prob (F) of 0.8345 , and the Breusch-Godfrey, which found a statistics $(\mathrm{F})$ of 0.8361 and prob $(\mathrm{F})$ of 0.5451 . Therefore, one can accept the null hypothesis of tests, which indicates the non-occurrence of the problem of heteroscedasticity. Finally, we verified the normality of residuals, using the Jarque-Bera test, which reported a prob $(\mathrm{F})$ of 0.8816 , which indicates their normality.

The result of regression analysis shows the variables significant at 5\%: $\log$ (DCL) consolidated net debt; FIRJAN index of human development (IFDM) and political party (PSDB). Regarding the variable political party, only the PSDB dummy is significant. However, since it is a dichotomous variable, one must maintain the final model of multiple linear regression, all the other dummies regardless if they are significant or not for the model. Moreover, the adjusted $\mathrm{R}^{2}$ is 0.407034 that is the level of explanation of the estimated final model is $40.70 \%$, and the statistics (F) is 12.32620 . While the two variables: log (DCL) consolidated net debt and FIRJAN index of human development (IFDM) show a positive relationship with the level of full disclosure (NET), the variable political party by means of dummy PSDB shows a negative relationship.

In this context, the results indicate that social indicators such as IFDM, economic issues related to the collection of prefectures (RCL) and the political party, of the mayor, are factors that explain the level of full disclosure of the municipalities. Along this line, studies of Santana Junior (2008) and Cruz et al. (2012) also point out that socioeconomic factors may explain the level of disclosure of public management. However, contrary to the findings of Cruz et al. (2012), the results indicate that the party affiliation of the mayor can explain the level of disclosure of municipalities, specifically the PSDB dummy. This indicates that mayors linked to the PSDB political party would not be concerned about its legitimacy, because the provision of these managers in evidence the public information is lesser compared with the other political parties investigated in this dissertation. While managers of municipalities with high IFDM and net current revenue (RCL) have a willingness to develop better policies of transparency and disclosure of information, which reduces the effects of information asymmetry and would reaffirm its legitimacy in society. 
Table 7 - Result of the final model estimate for the NEO index.

\section{Dependent Variable: NEO}

Method: Least Squares

Included Observations: 100

\begin{tabular}{l|llll}
\hline Variable & Coefficient & Std. Error & t-Statistic & Prob \\
IFDM & $\mathbf{5 7 , 5 7 6 3 7}$ & $\mathbf{1 9 , 4 0 6 7 2}$ & $\mathbf{2 , 9 6 6 8 2 7}$ & $\mathbf{0 , 0 0 3 8}$ \\
log GDP & $\mathbf{6 , 5 7 7 2 9 3}$ & $\mathbf{2 , 4 1 9 4 7 8}$ & $\mathbf{2 , 7 1 8 4 7 6}$ & $\mathbf{0 , 0 0 7 8}$ \\
Constant & $-60,70408$ & 21,78233 & $-2,786850$ & 0,0064 \\
\hline R- squared & 0,236070 & & Adjusted R- squared & $\mathbf{0 , 2 2 0 3 1 8}$ \\
F-statistic & $\mathbf{1 4 , 9 8 7 4 6}$ & & Prob (F - statistic) & $\mathbf{0 , 0 0 0 0 0 0}$ \\
Durbin-Watson & $\mathbf{2 , 1 7 1 5 6 2}$ & & \\
\hline
\end{tabular}

Furthermore, to identify the explanatory factors of the level of mandatory disclosure (NEO), we considered the measurement of the level of disclosure only in relation to the mandatory information. In this sense, the same procedures used to identify the NET explanatory factors were applied. Table 7 shows the results of estimated final model for NEO.

Therefore, the significant variables for the model at 5\% are FIRJAN index of municipal development (IFDM) and log GDP per capita (GDP). Moreover, the adjusted $\mathrm{R}^{2}$ is 0.220318 , which means that the level of explanation of the estimated final model is $22.03 \%$; and the statistics $(\mathrm{F})$ is 14.98746.

From the analysis of the estimated final model for NEO, it is noted that the variation of one unit of the variable FIRJAN index of municipal development (IFDM) causes increase of 57.5763 times on the NEO, and 1\% variation in the variable log (GDP) per capita GDP causes increase of 6.5772 times on the NEO. This means that the IFDM and GDP per capita are factors that explain the level of mandatory disclosure (NEO) of the investigated municipalities. 
Table 8 - Result of the final model estimate for the NEV index.

\section{Dependent Variable: NEV}

Method: Least squares

Included Observations: 100

\begin{tabular}{l|llll}
\hline Variables & Coefficient & Std. Error & t-Statistic & Prob \\
log POP & $\mathbf{3 , 6 8 3 5 8 0}$ & $\mathbf{1 , 0 5 3 7 5 8}$ & $\mathbf{3 , 4 9 5 6 6 1}$ & $\mathbf{0 , 0 0 0 7}$ \\
IFDM & $\mathbf{4 7 , 3 4 8 9 1}$ & $\mathbf{1 3 , 7 6 1 8 8}$ & $\mathbf{3 , 4 4 0 5 8 5}$ & $\mathbf{0 , 0 0 0 9}$ \\
log GDP & $\mathbf{3 , 2 9 3 0 9 2}$ & $\mathbf{1 , 5 7 8 4 8 2}$ & $\mathbf{2 , 0 8 6 2 4 0}$ & $\mathbf{0 , 0 3 9 6}$ \\
Constant & $-52,56098$ & 14,18921 & $-3,704293$ & 0,0004 \\
\hline R- squared & 0,414372 & & Adjusted R-Squared & $\mathbf{0 , 3 9 6 0 7 2}$ \\
F- statistic & $\mathbf{2 2 , 6 4 2 2 4}$ & & Prob (F - statistic) & $\mathbf{0 , 0 0 0 0 0 0}$ \\
Durbin-Watson & $\mathbf{2 , 1 8 5 2 4 2}$ & & & \\
\hline
\end{tabular}

Finally, there are the explanatory factors of level of voluntary disclosure of municipalities (NEV). Table 8 shows the results of the NEV estimated final model.

And thus, it was found that the significant variables for the model at 5\% are the FIRJAN index of municipal development (IFDM), the log population (POP) and log GDP per capita (GDP). Moreover, the adjusted $\mathrm{R}^{2}$ is 0.396072 that is the level of explanation of the estimated final model is $39.60 \%$, and the statistics $(\mathrm{F})$ is 22.64224 .

From the analysis of the estimated final model for NEV, the $1 \%$ variation of the variable log (POP) population causes increase of 3.683580 in NEV, the variation of one unit of the variable FIRJAN index of municipal development (IFDM) causes increase of 47.34891 times in NEV, and $1 \%$ variation in the variable $\log$ (GDP) per capita GDP causes increase of 3.293092 times on the NEV. Thus, the factors explaining the NEV are the population (POP), the IFDM and GDP per capita of municipalities.

After the results of the estimate multiple linear regression model for the NET, one can conclude the testing of hypotheses.

Hypothesis $\mathrm{H} 1$ implies the relation of NET and the location of the municipalities. In this sense, the statistical results show that the state variables (EST) and region (REG) are not significant to the model at 5\%. Consequently, $\mathrm{H} 1$ cannot be accepted. Thus, it is concluded 
that the municipalities' location does not explain the level of full disclosure of municipal management. This result precludes the finding of the study by Cruz et al (2012), which indicates the existence of a relationship between the level of municipal disclosure and the location of municipalities within their state.

The Hypothesis $\mathrm{H} 2$ implies the relation between NET and size of cities. The results of the statistical model indicated that the variables: land area (log AREA) and total population (POP $\log$ ) are not significant to the model at 5\%. Thus, $\mathrm{H} 2$ cannot be accepted. Thus, the size of cities does not explain their level of disclosure. This result is similar to the study by Pérez, Bolivar and Hernández (2008) that does not indicate the existence of a relationship between the NE and the population of municipalities. Nevertheless, it opposes the findings of Cruz et al. (2012) and Santana Junior (2008) who point out that the existence of a positive relationship between the level of disclosure and the population of municipalities in the case of the former, and the states in the case of the later.

The H3 hypothesis presupposes the relationship between NET and party affiliation of mayors. The results of the estimated regression model indicate that the variable political party, by means of dummy (PSDB), is significant for the model at 5\%, and exerts a negative influence on the NET. Thus, one cannot reject the hypothesis H3. It is concluded that the partisan affiliation of mayors is an explanatory factor of the level of disclosure of the municipalities. This result is similar to the findings from studies of Styles and Tennyson (2007), Gandía and Archidona (2008) and Grimmelikhujsen and Wech (2012). However, they object to the result of the study of Cruz et al. (2012), which indicates no relationship between the party affiliation of the mayor and the level of disclosure of the municipality.

The H4 hypothesis presupposes the relationship between NET and the economic indicators of municipalities. The results of the estimated regression model indicate that the variables GDP per capita (log GDP), resource transfers (log TRANSF), total Revenue (log REC_T) and consolidated net debt (log DCL) are not significant to the model at 5\%. However, the variable current net revenue ( $\log \mathrm{RCL})$ is significant for the model at 5\%. Thus, H3 cannot be rejected. And therefore, it is concluded that economic aspects of the cities, especially the amount of net current revenue is an explanatory factor of the level of disclosure. This result is similar to the findings of Styles and Tennyson (2007) and Cruz et al. (2012).

The H5 hypothesis presupposes the relationship between NET and the social indicators of the municipalities. The results of the estimated regression model indicate that the variables illiteracy rate (ANALF), human development index (HDI) and index of fiscal and social responsibility (IFRS) are not significant to the model at 5\%. However, the variable FIRJAN index of municipal development (IFDM) is significant for the model at 5\%. Therefore, H5 cannot be rejected. It is concluded that social indicators of municipalities, especially the (IFDM) is an explanatory factor of the level of disclosure of the municipalities. This result is similar to the findings of Pérez, Bolivar and Hernández (2008) and Cruz et al. (2012).

\section{Final Remarks}

The results of this study indicate that the overall level of disclosure of municipal 
administrations on average is low. No municipality showed all 86 indicators of information tested. Even the mandatory information was completely evidenced by municipalities. It was also found that the only indicator of information displayed by all municipalities surveyed with regard to the publication of news about the City Hall. Moreover, the information relating to members of the opposition to the municipal government is omitted by all public administrations studied.

To identify the explanatory factors of the level of disclosure, 5 hypotheses were tested. To each of them were related variables, which are estimated to be an explanatory factor in the level of disclosure. These variables were subjected to statistical model of multiple linear regression and therefore hypotheses $\mathrm{H} 1$ and $\mathrm{H} 2$ cannot be accepted, and $\mathrm{H} 3, \mathrm{H} 4$ and $\mathrm{H} 5$ cannot be rejected. Thus, the results of the estimated statistical model indicate that adherents, economic and socio-political aspects of the municipalities are explanatory factors with their levels of disclosure.

In this sense, the factors that explain the level of full disclosure of public management are: FIRJAN index of Municipal Development (IFDM), the net current revenue (RCL) and the political party of the mayor. Furthermore, it was found that while the first two positively affect the NET, the latter negatively influences the level of full disclosure of municipalities. Thus, it is concluded that managers in cities with better socioeconomic indices such as IFDM, more fundraising, as the net current revenue, have a higher willingness to show the information as its management face the town hall, which shows the concern of these managers to minimize the effects of information asymmetry and thus ensuring the maintenance of its legitimacy in society.

On the other hand, governors connected to the PSDB do not have a willingness to show public information. By not addressing the problem of information asymmetry through the disclosure of information, these managers are not concerned with the process of its legitimacy.

When analyzing only the level of mandatory disclosure (NEO), the statistical results indicate that the explanatory factors accounting for the NEO are: the FIRJAN index of municipal development (IFDM) and GDP per capita (GDP) of municipalities. The aspects that explain the level of voluntary disclosure (NEV) are: FIRJAN index of municipal development (IFDM), population (POP) and the GDP per capita of the surveyed municipalities.

This study did not consider other forms of disclosure of information than the use of the webpage available on the Internet. The level of disclosure determined considers the information on the set of indicators of information built, nor investigated the possible consequences of disclosure of public management, as well as the quality of the information highlighted.

As a suggestion for future studies, it is recommended to investigate the disclosure of other types of public information, as well as other forms of transparency on the Internet. The quality of information evidenced by municipalities could be the focus of other studies, as well as analysis of the consequences of disclosure of information regarding municipal 
management.

\section{References}

Arruda, Maria F; Teles, José S. (2010). A importância do controle social na fiscalização dos gastos públicos. Revista Razão Contábil e Finanças. Fortaleza, n. 1.

BRASIL. Lei $n^{o}$ 4.320, de 17 de março de 1964. Available in: <http://www.planalto.gov.br/ccivil_03/leis/14320.htm>.

BRASIL. Constituição da República Federativa do Brasil. 1988. Available in: <http://www.planalto.gov.br/ccivil_03/constituicao/constitui\%C3\%A7ao.htm>.

BRASIL. Lei $n^{o}$ 8.666, de 21 de junho de 1993. Available in: <http://www.planalto.gov.br/ccivil_03/LEIS/L8666cons.htm>.

BRASIL. Lei $n^{o}$ 9.755, de 16 de dezembro de 1998. Available in: <http://www.planalto.gov.br/ccivil_03/Leis/L9755.htm>.

BRASIL. Lei Complementar $n^{o}$ 101, de 4 de maio de 2000. Available in: <http://www.planalto.gov.br/ccivil_03/Leis/LCP/Lcp101.htm>.

BRASIL. Lei $n^{o}$ 10.028, de 19 de outubro de 2000. Available in: <http://www.planalto.gov.br/ccivil_03/leis/L10028.htm>.

BRASIL. Lei $n^{o}$ 10.257, de 10 de julho de 2001. Available in: <http://www.planalto.gov.br/ccivil/LEIS/LEIS_2001/L10257.htm>.

BRASIL. Lei Complementar $n^{o}$ 131, de 27 de maio de 2009. Available in: <http://www.planalto.gov.br/ccivil/leis/LCP/Lcp131.htm>.

BRASIL. Lei $n^{o}$ 12.527, de 18 de novembro de 2011. Available in: <http://www.planalto.gov.br/ccivil_03/_ato2011-2014/2011/lei/112527.htm>.

Bryant, Phil; Davis, Charlotte. (2012). Regulated change effects on boards of directors: A look at Agency Theory and Resource dependecy Theory. Academy of Strategic Management Journal, 11, (2).

Cruz, Cláudia F; Ferreira, Aracéli C. de S.; Silva, Lino M. da; Macedo, Marcelo Á. da S. (2012). Transparency of the municipal public management: a study from the homepages of the large Brazilian municipalities. Revista Administração Pública, 46, (1): 153-176.

Gàndia Juan L.; Archidona, Maria C. (2008). Determinants of web site information by Spanish city councils. Online information review, 32 (1).

Gerigk, Willson. O impacto da Lei de Responsabilidade Fiscal sobre a Gestão Financeira dos pequenos municípios do Paraná, Brasil. (2008). 315 f. Dissertation - PPGC - UFP, Curitiba, PR.

Grimmelikhuijsen, Stephan G; Welch, Eric, W. (2012). Developing and testing a theoretical framework for computer-mediated transparency of local governments, Public Administration 
review, 72 (4): 562-571.

Gujarati, Damodar. (2006). Econometria Básica. 4. ed. São Paulo: Makron Books.

Gupta, Aarti. (2008). Transparency Under Scrutiny: Information Disclosure in Global Environmental Governance. Global environmental politics, 8 (2).

Instituto Brasileiro de Geografia e Estatística (IBGE). (2012).Contagem da População 2010. Available in:< http://www.ibge.gov.br/home/estatistica/populacao/censo2010/default.shtm >. Accessed 14 set.

Manning, Nick; Krann, Dirk-Jan. (2006). The matrics of tracking in the public sector. XII International research Symposium on Public Management. Economic Cooperation and development.

Mendel, Toby. (2013). Freedom of information: a comparative legal survey. Organização das nações Unidas para a Educação, a Ciência e a Cultura (UNESCO), Brasília/DF, 2009. Available in: < http://www.unesco.org/new/pt/brasilia/> Accessed 5 fev.

Mello, Gilmar Ribeiro de.; Slomski, Valmor. (2010). Índice de Governança Eletrônica dos Estados Brasileiros (2009): no âmbito do poder executivo. JISTEM - Revista de Gestão da Tecnologia e Sistemas de Informação, 7 (2): 375-408.

Moreno Sardà, Amparo; Molina Rodríguez-Navas, Pedro; Corcoy, Marta; Aguilar, Antonio; Borras, Miguel. (2013). Inforparticip@: periodismo para la participación ciudadana em El control democrático. Critérios, metodologias y herramientas, em estudios sobre el mensaje periodístico. Universidade Complutense de Madrid, 19, (2): 783-803.

Moreno Sardá, Amparo; Molina Rodríguez-Navas, Pedro; Corcoy, Marta. (2013). La información de las administraciones públicas locales. Las webs de los ayuntamientos de Cataluña. Revista latina de Comunicação Social. La Laguna (Tenerife). Universidade de La Laguna. 68: 502-528. Available in: http://www.revistalatinacs.org/068/paper/987_Bellaterra/21_Moreno.html_DOI: 10.4185/RLCS-2013-987/CrossRef link. Accessed 22 mar. 2014.

Organização das Nações Unidas. (2007). Public Governance Indicators: A Literature Review Departamento de Assuntos Econômicos e Sociais.

Pérez, Carmen C.; Bólivar, Manuel P. R.; Hernández, Aantonio. M. López. (2008). E-Government process and incentives for online public financial information. Online information review, 33 (3): 379-400.

Programas das Nações Unidas para o Desenvolvimento(PNUD). Atlas do desenvolvimento humano no Brasil. (2013). Available in: 〈http//:www.pnud.org.br〉. Accessed 20 ago. 2013.

Relly, Jeannine E. e Meghna Sabharwal. (2009). Perceptions of transparency of government policymaking: A cross-national study. Government Information quarterly, 26 (1): 148-157.

Santana Junior, Jorge José Barros de. (2008). Transparência fiscal eletrônica: uma análise 


\section{Macrothink}

dos níveis de transparência apresentados nos sites dos poderes e órgãos dos estados e do Distrito Federal do Brasil. 177 f. Dissertation (Mestrado em Ciências Contábeis).

Saw, Kenneth W. (2013). Corporate disclosure quality, earnings smoothing, and earnings' timeliness. Journal of Business Research, Columbia, 56: 1043-1050.

Souza, Antônio A. de; Boina, Terence M.; Avelar, Ewerton A.; Gomide, Pedro L. R. (2008). Evidenciação Contábil nos Municípios Mineiros: Atendimento ao artigo 48 da Lei de Responsabilidade Fiscal. In: CBC - CFC, XVIII. Gramado, RS.

Styles, Alan K.; Tennyson, Mack. (2007). The accessibility of financial reporting of U.S. Municipalities on the Internet. Journal of Public Budgeting, accounting \& financial Management. 19 (1): 56-92.

\section{Copyright Disclaimer}

Copyright for this article is retained by the author(s), with first publication rights granted to the journal.

This is an open-access article distributed under the terms and conditions of the Creative Commons Attribution license (http://creativecommons.org/licenses/by/3.0/). 